Nig. J. Biotech. Vol. 38 (1) : 83-90 (June 2021)

ISSN: 01891731

Available online at

NIGERIAN JOURNAL OF

BIOTECHNOLOGY

http://www.ajol.info/index.php/njb/index

and www.biotechsocietynigeria.org

DOI: https://dx.doi.org/10.4314/njb.v38i1.10

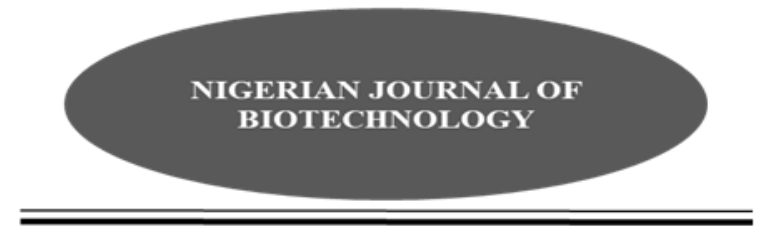

\title{
Haematological Indices and Carcass Composition of African Catfish Clarias gariepinus (Burchell, 1822) Fingerlings Fed with Fluted Pumpkin Leaf (Telfairia Occidentalis) as Feed Additives
}

\author{
${ }^{1}$ Ochokwu, I. J., ${ }^{2}$ Taiwo, M.A., and ${ }^{3}$ Bashir, S.Y. \\ ${ }^{1}$ Department of Fisheries and Aquaculture, ${ }^{2}$ Department of Food Science and Technology, Faculty of \\ Agriculture and Agricultural Technology, Federal University Dutsinma, PMB 5001, Katsina State - Nigeria \\ ${ }^{3}$ Department of Fisheries, Adamawa State Polytechnic, Yola.
}

Abstract

A feeding trial was carried out for 56 days to ascertain the effects of Telfairia occidentalis (fluted pumpkin) as a feed additive on the haematological profile and nutrients value of Clarias gariepinus carcass. C. gariepinus fingerlings (mean body weight $9.6 \mathrm{~g}$ ) were randomly distributed in plastic bowls at nine fish per bowl in triplicates. Five diets designated as D1 to D5 with $40 \%$ crude protein containing $0,50,100,150$, and $200 \mathrm{~g} / \mathrm{kg}$ of $\mathrm{T}$. occidentalis leaf powder were fed to $C$. gariepinus fingerlings at $5 \%$ body weight per day. The results showed that $T$. occidentalis additive significantly $(\mathrm{P} \leq 0.05)$ improved the haematological parameters of the fish. The mean value of white blood cells (WBC) count ( $\mu \mathrm{L}$ ) in the diets fed with $T$, occidentalis were significantly higher (D2-D5 : 870.20, 864.80, 840.30, 876.40, respectively) than the diet without $T$. occidentalis (D1 783.15). A similar trend was observed in PCV, MCV, MCHC, MCH, and platelets. However, HB D1 (control) had higher values than the diet containing $T$. occidentalis. Meanwhile, in carcass quality, there was an increase in the crude protein of all the fish but the group that consumed $T$. occidentalis had a higher carcass crude protein and lower lipid, while the control had a higher lipid value. Meanwhile, the initial values obtained before the feeding trials had lower crude protein and higher lipid value when compared with the fish that was fed with the experimental diet. In conclusion, $T$. occidentalis leaf meal can be utilized to improve the haematological parameters of the fish, with an increase in the WBC there is a high possibility of the fish to withstand pathogenic attacks because Blood is a major parameter that determines the physiological, immune, and nutritional status of an organism, also WBC are important blood constituents for defense against diseases, pathogens and unwanted foreign bodies in an organism.

Keywords: Haematology, Carcass quality, Telfairia occidentalis and Clarias gariepinus Correspondence Email: fineije@gmail.com; phone number +2348060907861 Introduction

The value of fish cannot be overemphasized. Considering the rate of increase in population, the demand for fish has necessitated an increase in aquaculture production (Ochokwu et al., 2019). However, there is a need to ascertain various ways of improving the well-being of the fish to reduce mortality, subsequently improve growth and increase yield (Ochokwu et al., 2014). Fish is an aquatic organism and are exposed to chemical compounds in the water which affect their haematological profiles (Onyia et al., 2015). Understanding the habitation, physiochemical, and haematological features of cultured fishes is essential for aquaculture development. However, haematological 
parameters are used to ascertain the health status of organisms including fish (Onyia et al., 2019). Each species of fish can vary in blood parameters depending on the fish type, the genetic makeup, the parent (Pamino et al., 2018) ; other causes of the blood variations includes mutation which can create new alleles in a population, random mating which can be a result of migration, random fertilization, recombination between homologous chromosomes during meiosis. However, PCV, Hemoglobin concentration, platelets, erythrocyte, leukocytes can be affected by nutrition, toxic substances in the water body, infectious diseases, environmental conditions, fish age, and iron deficiency. Onyia et al. (2019) reported that it is of high importance to ascertain the physiological status of fish health through the blood and the quality of the dietary nutrients consumed as it will aid to decipher the metabolic and health status of the fish.

T. occidentalis (fluted pumpkin) is cultivated and consumed in various parts of southern Nigeria, it can grow all year round, either during the rainy season or irrigation method during the dry season. The green leaf is utilized as food and herbal medicine. The leaf is an essential source of protein, oil, vitamins, and minerals but low in crude fiber and also a rich source of folic acid, calcium, zinc, potassium, cobalt, copper, iron, vitamins A, C, and $\mathrm{K}$ (Ajibade et al., 2006). T. occidentalis leaf has active ingredients: bioflavonoid, antioxidants, vitamins, thiamine, riboflavin, nicotinamide and ascorbic acid, phytochemicals like phenols, it is an active chemical, a growth promoter (Fasuyi and Nonyerem, 2007), that can similarly have effects in fish. The leaf has anti microbial and antiviral properties (Nwozo et al., 2004; Olorunfemi et al., 2005). The aqueous extract from $T$. occidentalis increases haematological parameters of an organism (Alada, 2000). The rate of increase in aquaculture in Nigeria and Africa and the need for quality fish has necessitated research to improve haematological parameters of the fish. Meanwhile, an increase in intensive fish rearing demands the source of natural feed additives, plants, leaves, and pulp. In place of the above, Udoh et al. (2017) utilized bitter leaf to improve the haematological response of $C$. gariepinus broodstock, Falaye et al. (2018) included Moringa leaf to improve C. gariepinus, Bbole et al. (2016) used $M$. oleifera leaf meal to increase the haematological parameters of Oreochromis niloticus, Mango leaf meal (Awad and Austin, 2010), while Anyanwu et al. (2015) used Alchornea cordifolia to improve the haematological responses of Heteroclarias. These plants and leaves have been employed as a growth promoter in fish and subsequently improve the haematological profile of the fish, in this research, T. occidentalis was used to improve carcass quality and haematological parameters of C. gariepinus fingerlings.

\section{Materials and methods}

\section{Source of Telfairia occidentalis}

T. occidentalis leaf was purchased from the major markets popularly known as the meat market and Ekeaba market in Ebonyi State - Nigeria.

\section{Preparation of Telfairia occidentalis}

T. occidentalis leaf is shown in Plate I. The fresh leaf was air-dried under room temperature. The dried $T$. occidentalis was grounded into powder form using mortar and pestle and sieved using a $0.8 \mathrm{~mm}$ mesh-size net to obtain fine particles for homogenous mixing as shown in plate II. The leaf meal powder was used to analyze nutrient composition, phytochemical and mineral elements according to (AOAC, 2012). 50, 100, $150,200 \mathrm{~g} / \mathrm{kg}$ of $T$. occidentalis were weighed and mixed with basal feed based on the formulation defined for African Catfish (C. gariepinus) according to (Onyia et al., 2015). 


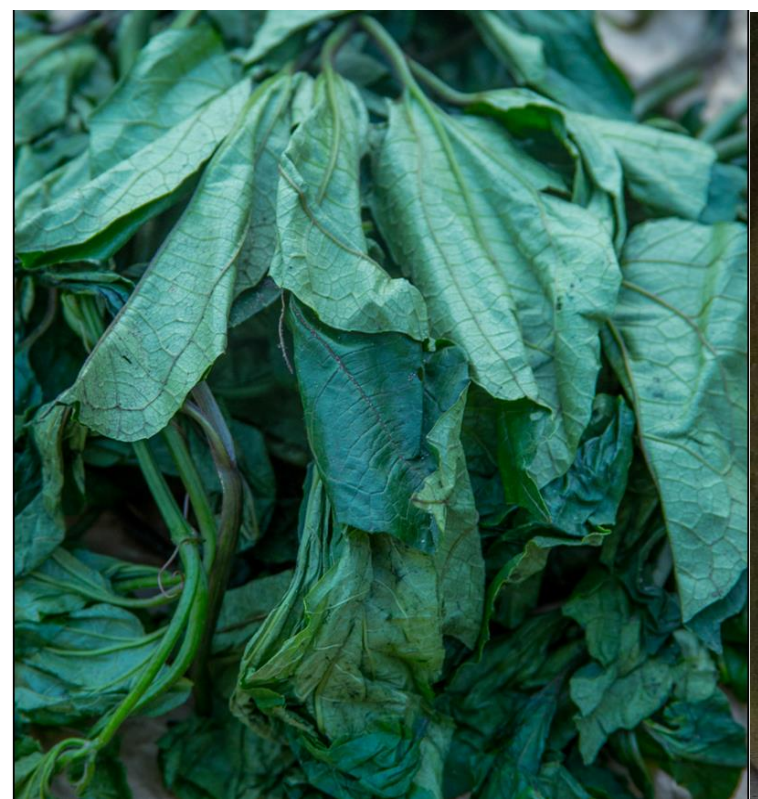

Plate I: T. occidentalis fresh leaf

\section{Experimental diet}

The experimental diets formulated contained $40 \%$ crude protein using the Pearson square method. Fish meal, soybean meal, groundnut cake meal, yellow maize, vitamin premix, cassava starch (binder), palm oil, sodium chloride were procured from the meat market in Abakaliki. Soybean was toasted for 10 minutes using a fabricated manual soybean roaster at $100^{\circ} \mathrm{C}$. Fish

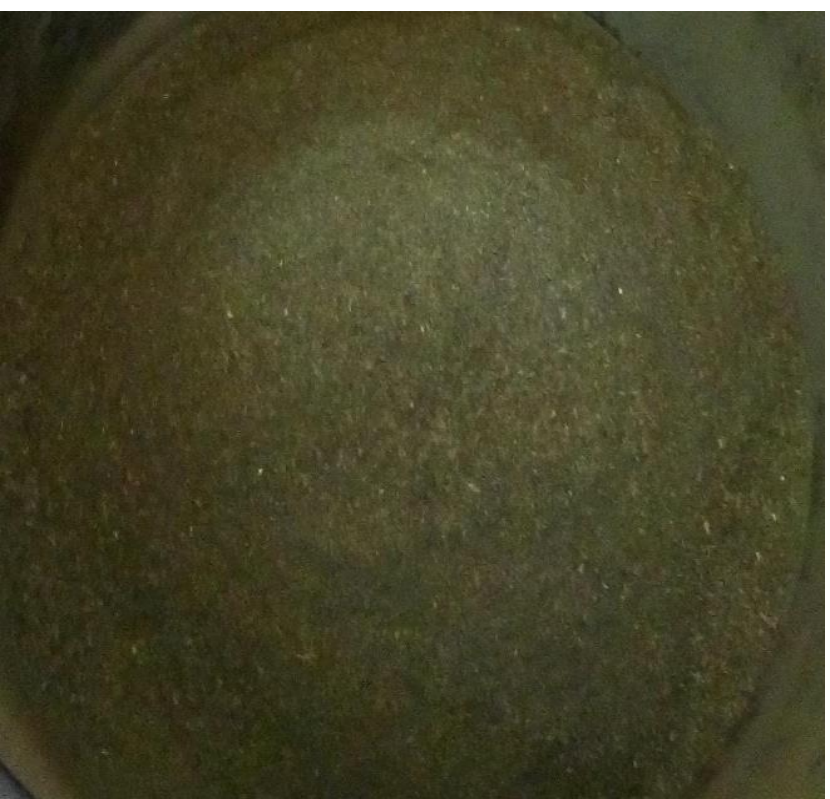

Plate II: T. occidentalis leaf meal in fine particles

meal, toasted soybean, groundnut cake, and yellow maize were ground separately using a hammer mill. All the feed ingredients were weighed with an electronic weighing balance (Model: Mettler Toledo PB 8001, London). The feed ingredients were thoroughly dried, mixed manually, and pelletized, the pellets were packed in a bag until the commencement of the research.

Table 1: Formulation of the Experimental Diets $(\mathrm{g})$ on Dry Matter Bases

\begin{tabular}{llllll}
\hline Ingredients & D1 (control) & D2 & D3 & D4 & D5 \\
\hline Fish meal & 350 & 350 & 350 & 350 & 350 \\
Soya bean meal & 200 & 200 & 200 & 200 & 200 \\
Groundnut cake & 200 & 200 & 200 & 200 & 200 \\
Yellow maize & 150 & 150 & 150 & 150 & 150 \\
Palm oil & 20 & 20 & 20 & 20 & 20 \\
Vitamin premix & 20 & 20 & 20 & 20 & 20 \\
Binder (starch) & 50 & 50 & 50 & 50 & 50 \\
Sodium chloride & 10 & 10 & 10 & 10 & 10 \\
T. occidentalis leaf meal (g) & 0 & 50 & 100 & 150 & 200 \\
$\%)$ T. occidentalis leaf meal & $0 \%$ & $5 \%$ & $10 \%$ & $15 \%$ & $20 \%$ \\
\hline
\end{tabular}

\section{Collection of experimental fish}

One hundred and thirty-five (135) fingerlings of C. gariepinus were procured from Oruna fish farm, Mgbukobe mile 50, Abakaliki in Ebonyi State, Nigeria. The fish was transported in plastic bowls (50 cm diameter $\times 30 \mathrm{~cm}$ deep) to the Teaching and Research Fish Farm of the
Department of Fisheries and Aquaculture, Ebonyi State University. The fingerlings were acclimated for 2 days (48hours) in a $10 \mathrm{~m}^{2}$ concrete pond.

\section{Experimental design}

Water was sourced from the experimental site. Nine (9) C. gariepinus fingerlings were stocked per trough for 5 different plastic troughs with three replications per treatment. Five 
isonitrogenous diets (40\% crude protein) were formulated. The control (D1) basal diet had no $T$. occidentalis leaf meal inclusion, while others had $50 \mathrm{~g}, 100 \mathrm{~g}, 150 \mathrm{~g}$, and $200 \mathrm{~g} / \mathrm{kg}$ of $T$. occidentalis inclusion designated as D2, D3, D4, and D5 respectively. All dietary ingredients were weighed with a weighing load balance (Mettler Toledo PB 8001 London). Ingredients such as vitamin premix were mixed with $T$. Occidentalis meal thoroughly to obtain a homogenous mass before mixing with other ingredients and pelleted. The pellets were sundried for some time, packed in a sack, and kept frozen until the commencement of the experiment. The experimental diet was assigned randomly to the tanks and each group of fish was fed at $5 \%$ body weight twice per day for 56 days. At the end of the feeding trials, the fish were analyzed for haematological indices and nutrients composition of the carcass.

\section{Evaluation of haematological indices}

At the end of the feeding trials, six (6) C. gariepinus juveniles were selected randomly from each plastic bowl and blood samples were collected to determine the haematological indices. Blood was deduced from the caudal vein of the fish using distinct heparinized disposable syringes and hypodermic needles (Onyia et al., 2019).

Haematocrit (Hct): it was estimated after centrifugation at $15000 \mathrm{rpm}$ using an MSE microcentrifuge.

Hemoglobin concentration $(\mathrm{Hb})$ : The indirect acid haematin (Sahli) procedure was employed. It involved using a hemoglobin meter and pipette. The concentration of Hemoglobin was converted to acid haematin using $0.1 \mathrm{M} \mathrm{HCl}$ and $0.02 \mathrm{~mL}$ pipette. The graduated tube was filled with 20 $\mathrm{mL}, 0.1 \mathrm{M} \mathrm{HCl}, 0.02 \mathrm{~mL}$ of blood sample was added. After 5 minutes, few drops of distilled water were added until the color matched the standard. Hemoglobin concentration was calculated via:

$\mathrm{Hbc}=$ Values obtained $\times 17.2 \mathrm{~g} / 100 \mathrm{~mL} \div 100$ Leucocyte count (LC): Haemocytometer was utilized. $0.8 \mathrm{~cm}$ objective of the microscope and large squares (area $=1 \mathrm{~mm}^{2}$, depth $=0.1 \mathrm{~mm}$ ) and the expected volume $0.1 \mathrm{~mm}^{3}$, dilution factor 20. Four squares were utilized and the total count per $\mathrm{mm}^{3}$ is:

$20 \times 1 \times \mathrm{L}$ cells $\div 0.4=50 \times \mathrm{L}$ cells where $\mathrm{L}$ represents the number of leukocytes that are counted.
Erythrocytes ( $E C$ ): Heparinized blood diluted by Hayman solution at a ratio of 1:200 was utilized. Neubauer improved hemocytometer placed on a compound microscope stage was employed to determine the erythrocyte population. The number of cells counted $R$, (average of two fields) was multiplied by the dilution factor while the volume of $1 / 4000 \mathrm{~mm} 3$ (area $=1 / 400 \mathrm{~mm} 3$, depth $=1 / 10 \mathrm{~mm}$ ), the count was done in 80 squares with the total volume of $1 / 50 \mathrm{~mm}^{3}$ the dilution factors was 200 . The Ec were:

$200 \times 50 \times \mathrm{R}$ cells $=10.000 \times \mathrm{R}$

Mean cell volume: The mean cell volume was calculated in picogram (pg) as:

$(\mathrm{MCV})=\mathrm{Hbc} \div \mathrm{Ec}$

Mean corpuscular hemoglobin concentration: It was calculated from the hemoglobin concentration values in $\mathrm{g} \mathrm{Lg}^{1}$ and from the hematocrit value using the following equation:

$\mathrm{MCHC}=\mathrm{Hbc} \div \mathrm{Hct} \times 1000$

\section{Carcass analysis}

Two fishes were randomly chosen from each treatment and the whole fish was used for proximate analysis according to AOAC, 2012.

Statistical analysis

Data collected were analyzed statistically using Analysis of variance; while differences between the means were separated using Duncan Multiple Range Test (DMRT) using SAS (Statistical Analysis System) version 8.

\section{Results}

Table 2 shows the Proximate and mineral analysis of $T$. occidentalis Leaf meal. The leaf meal enclose moisture content $8.5 \%$, crude protein $24.39 \%$, fat $3.20 \%$, crude fiber $14.33 \%$, ash $7.21 \%$, and Nitrogen free extract $34.37 \%$ respectively.

The mineral compositions analyzed are sodium $68.72 \mathrm{mg} / \mathrm{l}$, calcium $52.32 \mathrm{mg} / \mathrm{l}$, iron $18.99 \mathrm{mg} / \mathrm{l}$, magnesium $43.9 \mathrm{mg} / \mathrm{l}$, potassium $257.0 \mathrm{mg} / \mathrm{l}$ and zinc $17.5 \mathrm{mg} / \mathrm{l}$ respectively.

Table 3 presents the phytochemical composition of $T$. occidentalis leaf meal. It contains Tannins 1.16 , saponins 2.28, Alkaloids 1.80, flavonoids 2.65, and phenols 0.91 .

Table 4 shows the proximate composition of formulated feeds with varying inclusion levels of T. occidentalis leaf meal. The crude protein for diet 1 to diet 5 ranged from 39.79 in diet 5 to 40.60 in diet 3 , crude lipid ranged from 18.80 in 
diet 5 to 26.01 in diet 1 , meanwhile the crude fiber content ranged from 1.43 in diet 1 to 4.77 in diet 5 , while moisture content was 5.33 in diet 1 to 8.83 in diet 5 , ash ranged from 8.28 in diet
1 to 10.13 in diet 5, while nitrogen-free extract ranged from 17.14 in diet 3 to 19.02 in diet 4 respectively.

Table 2: Nutrient Composition and \% Dry Matter Basis of T. occidentalis leaf Meal

\begin{tabular}{ll}
\hline Nutrient and Mineral Compositions & Values \\
\hline Moisture Content & $8.5 \%$ \\
Crude Protein & $24.39 \%$ \\
Fat & $3.20 \%$ \\
Crude Fiber & $14.33 \%$ \\
Ash & $7.21 \%$ \\
Nitrogen Free Extract & $34.37 \%$ \\
Sodium & $68.72 \mathrm{mg} / \mathrm{l}$ \\
Calcium & $52.32 \mathrm{mg} / \mathrm{l}$ \\
Iron & $18.99 \mathrm{mg} / \mathrm{l}$ \\
Magnesium & $43.9 \mathrm{mg} / \mathrm{l}$ \\
Potassium & $257.0 \mathrm{mg} / \mathrm{l}$ \\
Zinc & $17.5 \mathrm{mg} / \mathrm{l}$ \\
\hline
\end{tabular}

Table 3: Phytochemical Composition of T. occidentalis Leaf Meal

\begin{tabular}{ll}
\hline Phytochemical Composition & $\%$ \\
\hline Tannins & 1.16 \\
Saponins & 2.28 \\
Alkoloids & 1.80 \\
Flavonoids & 2.65 \\
Phenols & 0.91 \\
\hline
\end{tabular}

Table 4: Proximate Composition of Experimental Diet

\begin{tabular}{llllll}
\hline & \multicolumn{5}{c}{ Dietary Treatments } \\
Nutrients \% & D1 & D2 & D3 & D4 & D5 \\
\hline Crude protein & 40.23 & 40.15 & 40.60 & 40.13 & 39.79 \\
Crude lipid & 26.01 & 25.08 & 22.24 & 19.00 & 18.80 \\
Crude fiber & 1.43 & 2.13 & 3.24 & 3.81 & 4.77 \\
Moisture content & 5.33 & 6.35 & 7.20 & 8.13 & 8.83 \\
Ash & 8.28 & 9.12 & 9.58 & 9.91 & 10.13 \\
Nitrogen Free Extract & 18.72 & 17.17 & 17.14 & 19.02 & 17.68 \\
\hline
\end{tabular}

Table 5 revealed the haematological parameters of C. gariepinus fingerlings fed with $T$. occidentalis. The Erythrocytes ranged from 2.23 in diet 1 to 3.61 in diet 5, leukocytes is from 783.15 I diet 1 to 876.40 in diet 5, PCV 46.20 in diet1 to 54.32 in diet 5, while MCV ranged from
134.80 in diet 1 to 139.35 in diet 5, MCHC ranged from 29.68 in diet 1 to 32.08 in diet $5, \mathrm{Hb}$ had 13.21 in diet 5 to 13.85 in diet $4, \mathrm{MCH}$ ranged from 38.20 in diet 1 to 41.25 in diet 5 , while platelets ranged from 68.30 in diet 5 to 95.20 in diet 1 respectively.

Table 5: Haematological parameters of Clarias gariepinus fingerlings fed experimental diets

\begin{tabular}{llllll}
\hline Parameters & D1 & D2 & D3 & D4 & D5 \\
\hline Mean weight $(\mathrm{g})$ & $19.7^{\mathrm{c}}$ & $24.2^{\mathrm{a}}$ & $20.2^{\mathrm{b}}$ & $20.1^{\mathrm{b}}$ & $20.5^{\mathrm{b}}$ \\
Erythrocytes $(\mu \mathrm{L})$ & $2.23^{\mathrm{c}}$ & $3.63^{\mathrm{a}}$ & $3.55^{\mathrm{a}}$ & $3.42^{\mathrm{b}}$ & $3.61^{\mathrm{a}}$ \\
\hline
\end{tabular}




\begin{tabular}{llllll}
\hline Leukocytes $(\mu \mathrm{L})$ & $783.15^{\mathrm{d}}$ & $870.20^{\mathrm{a}}$ & $864.80^{\mathrm{b}}$ & $840.30^{\mathrm{c}}$ & $876.40^{\mathrm{a}}$ \\
PCV $(\%)$ & $46.20^{\mathrm{c}}$ & $54.40^{\mathrm{a}}$ & $53.90^{\mathrm{b}}$ & $54.20^{\mathrm{a}}$ & $54.32^{\mathrm{a}}$ \\
MCV $(\mathrm{pg})$ & $134.80^{\mathrm{b}}$ & $139.15^{\mathrm{a}}$ & $138.90^{\mathrm{a}}$ & $138.65^{\mathrm{a}}$ & $139.35^{\mathrm{a}}$ \\
MCHC $\left(\mathrm{g} / \mathrm{dL}^{-1}\right)$ & $29.68^{\mathrm{c}}$ & $32.12^{\mathrm{a}}$ & $30.98^{\mathrm{b}}$ & $31.15^{\mathrm{b}}$ & $32.08^{\mathrm{a}}$ \\
$\mathrm{Hb}\left(\mathrm{g} / \mathrm{dL}^{-1}\right)$ & $14.98^{\mathrm{a}}$ & $14.45^{\mathrm{a}}$ & $14.05^{\mathrm{a}}$ & $13.85^{\mathrm{b}}$ & $13.21^{\mathrm{b}}$ \\
MCH $(\mathrm{pg})$ & $38.20^{\mathrm{c}}$ & $40.10^{\mathrm{b}}$ & $39.72^{\mathrm{bc}}$ & $40.60^{\mathrm{b}}$ & $41.25^{\mathrm{a}}$ \\
Platelets & $95.20^{\mathrm{a}}$ & $86.10^{\mathrm{b}}$ & $74.30^{\mathrm{c}}$ & $67.00^{\mathrm{d}}$ & $68.30^{\mathrm{d}}$ \\
\hline
\end{tabular}

Means with different superscripts on the same row are significantly different $(P \leq 0.05)$

The nutrient composition of the carcass of $C$. gariepinus fingerlings fed the experimented diets are revealed in table 6 . Crude protein ranged from $60.26 \%$ in diet 1 to $64.98 \%$ in diet 3 , while crude lipid ranged 10.01 in diet 3 to 14.13 in diet 1 , crude fiber ranged from 1.50 in diet 1 to
4.10 in diet 5 , ash contents was 2.02 in diet 1 to 4.03 in diet 5 , while moisture contents were 7.08 in diet 1 to 8.97 in diet 5 , nitrogen-free extract ranged from 8.02 in diet 5 to 12.99 in diet 1respectively.

Table 6: Nutrient Composition of the carcass of C. gariepinus fingerlings fed the experimented diets

\begin{tabular}{lllllll}
\hline Parameters & $\begin{array}{l}\text { Initial } \\
\text { carcass value }\end{array}$ & D1 & D2 & D3 & D4 & D5 \\
\hline Crude protein (\%) & $54.2^{\mathrm{d}}$ & $61.26^{\mathrm{bc}}$ & $64.01^{\mathrm{a}}$ & $64.98^{\mathrm{a}}$ & $63.10^{\mathrm{ab}}$ & $64.73^{\mathrm{a}}$ \\
Crude lipid (\%) & $23.62^{\mathrm{a}}$ & $14.13^{\mathrm{b}}$ & $11.20^{\mathrm{bc}}$ & $10.01^{\mathrm{c}}$ & $10.10^{\mathrm{c}}$ & $10.15^{\mathrm{c}}$ \\
Crude Fibre (\%) & $3.21^{\mathrm{ab}}$ & $2.50^{\mathrm{c}}$ & $2.50^{\mathrm{c}}$ & $2.64^{\mathrm{c}}$ & $3.07^{\mathrm{b}}$ & $4.10^{\mathrm{a}}$ \\
Ash (\%) & $4.12^{\mathrm{a}}$ & $2.02^{\mathrm{c}}$ & $2.33^{\mathrm{c}}$ & $2.99^{\mathrm{bc}}$ & $3.20^{\mathrm{b}}$ & $4.03^{\mathrm{a}}$ \\
Moisture (\%) & $7.41^{\mathrm{b}}$ & $7.10^{\mathrm{b}}$ & $7.83^{\mathrm{ab}}$ & $7.73^{\mathrm{b}}$ & $7.93^{\mathrm{ab}}$ & $8.97^{\mathrm{a}}$ \\
NFE (\%) & $7.44^{\mathrm{cd}}$ & $12.99^{\mathrm{a}}$ & $12.13^{\mathrm{a}}$ & $11.65^{\mathrm{b}}$ & $12.60^{\mathrm{a}}$ & $8.02^{\mathrm{c}}$ \\
\hline
\end{tabular}

Means with different superscripts on the same row are significantly different $(P \leq 0.05)$

\section{Discussion}

The research uncovered $T$. occidentalis leaf meal as a resource method of improving haematological profile and carcass quality of African catfish C. gariepinus fingerlings. It contains nutritional and phytochemical properties that aid to improve the physiological and biochemical effects in fish. It exposed the possibility of utilizing it to improve the blood profile in fish (Onyia et al., 2015). The proximate, phytochemicals and mineral composition of $T$. occidentalis agreed with the findings of (Idowu et al., 2019, Akwukwaegbu et al., 2016 and Mohd et al., 2016) who obtained a close range of proximate, phytochemical, and mineral composition of $T$. occidentalis.

Researchers reported the health of fish based on the relationship between weight and length. However, Onyia et al (2019) reported the essentiality to ascertain the physiological concept of fish health concerning its haematological profile, nutrition, and the quality of dietary protein intake. Any changes in the constituents/components of the blood sample when compared to the normal values could be used to interpret the metabolic state of the fish and the health status (Onyia et al., 2015). Meanwhile, blood is a major index of the physiological, immunopathological, and nutritional status of an organism. The result shows a significant difference $(P \leq 0.05)$ in all the treatments. It revealed that the fish which consumed $T$. occidentalis were higher in PCV

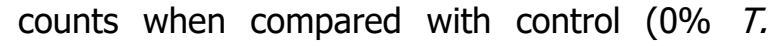
occidentalis), this disagreed with (Idowu et al., 2019) who obtained low values in PCV, however it agreed with (Onyia et al., 2015) who obtained higher PCV in $C$. gariepinus. The higher PCV obtained in this research denotes the importance of including $T$. occidentalis in the diet of $C$. gariepinus. Meanwhile, the values obtained in the red blood cell (Erythrocytes), Hb concentration agreed with (Idowu et al., 2019 and Onyia et al., 2015). There was a significant difference $(P \leq 0.05)$ among the treatments in the result obtained for white blood cell (Leukocytes), White 
blood cell counts in an organism express their value in the ability of the animal to resist the invasion of pathogens. It is vital in the immune response of the animal. The high WBC among the treatments in this study denote the well-being of the fish and its ability to withstand pathogen invasion during the culture period, meanwhile Diet 2 and Diet 5 had the highest value of leukocytes, which could be an indication that the inclusion of $T$. occidentalis leaf meal in $C$. gariepinus had a better effect on fish leukocytes populations when compared with other diets. Platelet (thrombocytes) count is formed from pieces of cells in the bone marrow known as megakaryocytes. However, megakaryocytes circulate through the bloodstream and can lead to blood clotting. Meanwhile, the clotting of blood quickens the healing process and prevents excess blood loss in the case of injury. In this research, the value obtained for platelets value agreed with (Idowu et al., 2019).

The nutrient values of the $C$. gariepinus carcass fed $T$. occidentalis leaf meal exposed the potency of $T$. occidentalis leaf meal as additives in the diet of $C$. gariepinus. In this study, there was a significant difference across the treatments. There was an increase in the crude protein of the fish fed with $T$. occidentalis when compare with the diet without $T$. occidentalis and reduction in the crude lipid this disagree with (Idowu et al., 2019) who recorded a reduction in the crude protein and an increase in the lipid content. However, there was a significant difference between the group fed with the treatments and the initial nutrient values obtained from the fish before the commencement of the feeding trial.

\section{Conclusion}

Considering the findings of the research, it could be implied that $T$. occidentalis leaf meal is very rich in protein; inclusion of $T$. occidentalis leaf meal significantly $\mathrm{P} \leq 0.05$ improved the haematological parameters of the fish such as PCV, Leukocytes, platelets, and MCV. It also improved the quality of the carcass in terms of crude protein, fiber and reduced the lipid content of the carcass. It points out that it can be utilized as plant additives in the diets of $C$. gariepinus.

\section{References}

Ajibade, S.R, Balogun M.O, Afolabi O.O, and Kupolati M.D. (2006) Sex differences in the biochemical contents of Telfairia occidentalis Hook F. J. Food Agric. Environ. 4(1): 155-156, DOI: https://doi.org/10.1234/4.2006.712

Akwukwaegbu, P. I., Peters, D. E., Wegwu, M. O. (2016) Proximate Analysis and Phytochemical Screening of Fluted Pumpkin (Telfairia occidentalis) Pod. American Journal of Food, Nutrition, and Health, 1(1): 1-6

Alada, A.R.A. (2000). The haematological effects of Telfairia occidentalis diet preparation. Afr. J. Biomed Res. 3(3): 185-186.

AOAC. (2012). Official Methods of Analysis. $16^{\text {th }}$ ed. Association of Official Agricultural Chemists. Washington. D.C. USA. Accessed on 21/09/2019.

Awad E, Austin D, Lyndon AR. 2013. Effect of black cumin seed oil (Nigella sativa) and nettle extract (Quercetin) on the enhancement of immunity in rainbow trout, Oncorhynchus mykiss (Walbaum). Aquaculture, 388(391): 193-197.

Bbole, I, Mumba, C., Mupenda, N., and Kefi, A.S. (2016). Analysis of growth performance and haematological parameters of Oreochromis niloticus fed on a varying diet of Moringa oleifera Lam. leaf meal as an additive protein source. Int. J. Fish. Aquac. 8(11):105-111, DOI: 10.5897/IJFA2016.0570

Chuku, L.C. and A.A. Uwakwe, 2012. Haematological and biochemical studies on some species of Fishes. J. Appl. Sci. Environ. Manage. 16: 275-279.

Fasuyi, A.O, Nonyerem A.D. (2007) Biochemical, nutritional and haematological implications of Telfairia occidentalis leaf meal as a protein supplement in broiler starter diets. Afr. J. Biotechnol. 6(8): 1055-1063.

Falaye, A.E., Omoike A and Awhefeada K.O (2018). The Hematological parameters of Catfish (Clarias gariepinus) fed Fish Feeds with replaced Premix using Moringa Leaf Meal (MLM) Madridge J. Aquac. Res. Dev., 2(1): 35-39

Idowu, T. A., Denham, S. A., and Adedeji, H. A. (2019). Growth Performance and Haematological indices of Clarias gariepnus Fingerlings Fed 
Varying Inclusion Levels of Telfairia occidentalis Leaf Meal Additives. Int. J. Fish. Aqua. Stud., $7(5): 442-445$

Mohd, A.M., Idris, M.B., and Abdulrasheed, A. (2016) The Mineral Composition and Proximate Analysis of $T$. occidentalis (Fluted Pumpkin) Leaves Consumed in Kano Metropolis, Northern Nigeria. American Chem. Sci. J., 10(1): 1-4, DOI: 10.9734/ACSJ/2016/20632

Nwozo, S.O, Adaramoye, O.A, Ajaiyoba, E.O. (2004). Antidiabetic and hypolipidemic studies of Telfairia occidentalis on alloxan - induced diabetic rats. Nig. J. Nat. Prod. Med. 8: 45-47. DOI: $\underline{10.4314 / \text { njnpm.v8i1.11814 }}$

Ochokwu, I. J., Onyia, L. U. and Ajijola, K. O (2014). Effect of Azanza garckeana (Goron Tula) Pulp Meal Inclusion on Growth Performance of Clarias gariepinus Broodstock (Burchell, 1822). Nig. J. Tropical Agric., 14: 134-146

Ochokwu, I. J., Nwabunike, M. O., and Udeh, G. N. (2019). Evaluation of Milt Quality of Clarias anguillaris (Linnaeus, 1758) Broodstock Fed Varying Inclusion Levels of Wild Hibiscus Azanza garckeana Pulp Meal. J. aquatic sci. 34(1): 23-31. DOI: $10.4314 /$ jas.v34i1.4

Olorunfemi A.E, Arnold C.I, Emmanuel O, Nkaima $\mathrm{N}$, Akeem A. (2005). Hypoglycaemic activity of
Telfairia occidentalis in rats. J. Pharm. Biores, 2: 36-42. DOI: $10.4314 / j p b . v 2 i 1.32059$

Onyia, L. U., Ochokwu, I. J. and Edison, E. S. (2019). Comparison of Haematological Indices, Blood Group and Genotype of Chrysicthys Nigrodigtatus and Synodontis Batensoda from Geriyo Lake, J. Aquatic Sci. 34 (1): 49-56, DOI: $\underline{10.4314 / j a s . v 34 i 1.7}$

Onyia, L. U., Diyaware, M. Y., Michael, K. G., Musa, M. and Ochokwu, I. J. (2015). Comparison of Haematological Indices, Blood Group and Genotype of Clarias gariepinus (Burchell, 1822) and Clarias anguillaris (Linneaus, 1758). 10(5):392-399. J. Fish. Aquat. Sci.

DOI: $10.3923 /$ jfas.2015.392.399

Pamino, V., Cappello, T., Costa, G., Cannavà, C., Sanfilippo, M., Fazio, F. and Fasulo, S. (2018). Comparative Study of Haematology of two teleost fish (Mugil cephalus and Carassius auratus) from different Environments and Feeding Habits. The European Zoolo. J., 85(1): 193-199. doi.org/10.1080/24750263.2018.1460694.

Udoh, J. P., Emah, A. H., George, I. E., and Aniedi, E. P. (2017) Growth Performance and Haematoogical Response of Clarias gariepinus Broodstock Fed Diets Enriched with Bitter Leaf Meal. AACL Bioflux 10(5): 1281-1296. www. bioflux.com.ro/aacl 